\title{
Policing the Global Crisis
}

\author{
William I. Robinson \\ University of California at Santa Barbara \\ wirobins@soc.ucsb.edu
}

As part of my research for a book manuscript on the crisis of global capitalism I recently finished writing (Robinson forthcoming), I decided to re-read the classic 1978 study conducted by the noted socialist and cultural theorist Stuart Hall and several of his colleagues, Policing the Crisis. The authors show in that book how the restructuring of capitalism as a response to the crisis of the 1970s - which was the last major crisis of world capitalism until the current one hit in 2008 led in the United Kingdom and elsewhere to an "exceptional state," by which they meant a situation in which there was an ongoing breakdown of consensual mechanisms of social control and a growing authoritarianism. They wrote:

This is an extremely important moment: the point where, the repertoire of hegemony through consent having been exhausted, the drift towards the routine use of the more repressive features of the state comes more and more prominently into play. Here the pendulum within the exercise of hegemony tilts, decisively, from that where consent overrides coercion, to that condition in which coercion becomes, as it were, the natural and routine form in which consent is secured. This shift in the internal balance of hegemony - consent to coercion - is a response, within the state, to increasing polarization of class forces (real and imagined). It is exactly how a 'crisis of hegemony' expresses itself....the slow development of a state of legitimate coercion, the birth of a 'law and order' society...the whole tenor of social and political life has been transformed by [this moment]. A distinctively new ideological climate has been precipitated (Hall et. al. 1978: 320-321).

In my view, this is an accurate description of the current state of affairs. We are already witnessing transitions from social welfare to social control states around the world. We are facing a global crisis that is unprecedented, given its magnitude, its global reach, the extent of ecological degradation and social deterioration, and the sheer scale of the means of violence. We truly face a crisis of humanity; we have entered a period of great upheavals, of momentous changes and uncertainties. This system-wide crisis is distinct from earlier such episodes of world crisis in the 1930s or the 1970s precisely because world capitalism is fundamentally different in early $21^{\text {st }}$ century.

Among the qualitative shifts that have taken place the capitalist system in the face of globalization in recent decades, there are four I want to underscore. First is the rise of truly transnational capital and the integration of every country into a new globalized production and financial system. Second is the appearance of a new transnational capitalist class (TCC). This is a class group grounded in new global circuits of accumulation rather than the older national 
circuits. Third is the rise of what I term transnational state apparatuses. And fourth is the appearance of novel relations of inequality and domination in global society, including an increasing importance of transnational social and class inequalities relative to North-South inequalities.

\section{The Current Crisis}

At the same time, the current crisis shares several aspects with earlier structural crises of the 1970s and the 1930s, but also several features unique to present. These include:

- The system is fast reaching the ecological limits of its reproduction. We have already reached several of what environmental scientists refer to as "tipping points." This dimension cannot be underestimated.

- The sheer magnitude of the means of violence and social control, as well as the magnitude of, and the extent of control over, the means of global communications and the production and circulation of symbols and images. In this regard, we are witness to frightening new systems of social control and repression that we need to analyze and to resist.

- We are reaching limits to the extensive expansion of capitalism, in the sense that there are no longer any new territories of significance to be integrated into world capitalism. Deruralization is now well advanced, and the commodification of the countryside and of pre- and non-capitalist spaces has intensified, that is, converted in hot-house fashion into spaces of capital, so that intensive expansion is reaching depths never before seen.

- The rise of a vast "surplus" population inhabiting a "planet of slums," alienated from the productive economy, thrown into the margins, and subject to sophisticated systems of social control and to destruction - to what I call a mortal cycle of dispossessionexploitation-exclusion. (see Sassen's contribution to this symposium)

- The disjuncture between a globalizing economy and a nation-state based system of political authority. Transnational state apparatuses are incipient. They have not been able to play the role of what world-systems theorists refer to as a "hegemon" or a leading nation-state with enough power and authority to organize and stabilize the system.

With this as context, let us review how the current crisis has developed. Emergent transnational capital underwent a major expansion in the 1980s and 1990s. This involved what we could call hyper-accumulation, achieved through a number of factors. These include the introduction of new technologies, above all through computerization, informatics and the internet. They also include neo-liberal policies that opened up the world to transnational capital and to new modalities of mobilizing and exploiting the global labor force, including a massive new round of "primitive accumulation" - the uprooting and displacement of hundreds of millions of people, especially in the Third World countryside, who have become internal and transnational migrants. 
But by the late 1990s, stagnation in the global economy set in. The system was again facing renewed crisis. Sharp global social polarization and escalating inequalities worldwide fueled the chronic problem of "overaccumulation.” Quite simply, global inequalities and the impoverishment of broad majorities mean that transnational capital cannot find productive outlets to unload enormous amounts of surplus it has accumulated. By the start of the $21^{\text {st }}$ century the TCC turned to several mechanisms to sustain global accumulation (profit-making) in the face of stagnation and overaccumulation.

One of the mechanisms is what I term militarized accumulation. This involves making wars and undertaking interventions that unleash cycles of destruction and reconstruction, and generate enormous profits for an ever-expanding "military-prison-industrial-security-energy-financial complex." We are now living in a global war economy that goes well beyond such "hot wars" as in Iraq, Afghanistan, or Syria. Another is the raiding and sacking of public budgets. The TCC uses its financial power to take control of state finances and impose further austerity on working majorities. The TCC employs its structural power (its control over the global economy) to accelerate the dismantling of what remains of the social wage and welfare states. And a third mechanism is frenzied worldwide financial speculation - turning the global economy into a giant casino. The TCC has unloaded trillions of dollars into speculation in housing and real estate markets, into food, energy and other global commodities markets, into bond markets worldwide (that is, into public budgets and state finances), and into every imaginable derivative.

\section{The Threat of " $21^{\text {st }}$-Century Fascism”}

How have social and political forces worldwide responded to crisis? The crisis has resulted in a rapid political polarization in global society. Both right and left-wing forces are ascendant. Among others, I want to highlight three responses to the crisis that seem to be in dispute.

One is what we could call "reformism from above." This reformism is aimed at stabilizing the system, at saving the system from itself and from more radical responses from below. Nonetheless, in the years following the 2008 collapse of the global financial system it seems these reformers are unable (or unwilling) to prevail over the power of transnational financial capital. A second response is popular, grassroots and leftist resistance from below. As social and political conflict escalates around the world there appears to be a mounting global revolt. While such resistance appears insurgent in the wake of 2008 it is spread very unevenly across countries and regions and facing many problems and challenges.

Yet another response is that I term $21^{\text {st }}$-century fascism. The ultra-right is an insurgent force in many countries. In broad strokes, this project seeks to fuse reactionary political power with transnational capital and to organize a mass base among historically privileged sectors of the global working class - such as white workers in the North and middle layers in the South that are now experiencing heightened insecurity and the specter of downward mobility. It involves militarism, extreme masculinization, homophobia, and racism and a racist mobilization against scapegoats, which includes the search for scapegoats (such as immigrant workers and, in the West, Muslims). $21^{\text {st }}$-century fascism evokes mystifying ideologies, often involving race/culture supremacy and xenophobia, embracing an idealized and mythical past. Neo-fascist culture normalizes and glamorizes warfare and social violence: indeed, generates a fascination with domination that is portrayed even as heroic. 
It is important to stress that the need for dominant groups around the world to secure widespread, organized mass social control of the world's surplus population and rebellious forces from below gives a powerful impulse to projects of $21^{\text {st }}$-century fascism. Simply put, the immense structural inequalities of the global political economy cannot easily be contained through consensual mechanisms of social control, that is, through hegemonic domination. With this in mind, let me turn by way of conclusion to five points with regard to policing global capitalism that I put forward for open-ended debate.

\section{A Global Police State}

First, policing global capitalism through new modalities of globalized social control and repression is absolutely not just a project of this $21^{\text {st }}$-century fascism; in fact, it is advanced by liberal and reformist elites and states. It is a structural, system-maintenance imperative of global capitalism.

Second, in thinking about policing global capitalism, we should ask: who does the system most need to police? Here, I want to call attention to rising tide of surplus labor. Instead of attempting to incorporate those marginalized, the system tries to isolate and neutralize their real or potential rebellion by criminalizing the poor and the dispossessed, with tendencies towards genocide in some cases. The mechanisms of coercive exclusion include: mass incarceration and prison-industrial complexes, pervasive policing, repressive anti-immigrant legislation, manipulation of space in new ways so that both gated communities and ghettos are controlled by armies of private security guards and technologically advanced surveillance systems, and ideological campaigns aimed at seduction and passivity through petty consumption and fantasy.

New forms of social control and modalities of ideological domination blur boundaries, so that there may be a constitutional and normalized neo-fascism, with formal representative institutions - a constitution, political parties, and elections - while all the while the political system is tightly controlled by transnational capital and its representatives. Any dissent that actually threatens the system is neutralized if not liquidated.

Third, we must recognize that criminalization and militarized control of the structurally marginalized as mechanisms of preemptive containment is highly racialized. This brings us back to Hall and his colleagues. In their 1978 study they highlighted the highly racialized nature of policing and the criminalization of black and immigrant communities in the United Kingdom. They deconstructed the complex ideological process of fabricating the criminalization of the oppressed in function of social control at moments of hegemonic crisis.

Here we see strong parallels between the incipient "exceptional state" in the 1970s and the current drift towards such states in the United States and elsewhere. The displacement of social anxieties to crime and racialized, “criminalized" populations in the United States and elsewhere dates back to the 1970s crisis. In the United States, in the wake of the mass rebellions of the 1960s, dominant groups promoted systematic cultural and ideological "law and order" campaigns to legitimate the shift from a social welfare to a social control state and the rise of a prison-industrial complex.

"Law and order" came to mean the reconstruction and reinforcing of racialized social hierarchies and hegemonic order in the wake of the 1960s rebellions. This coincided with global economic restructuring, neo-liberalism, and capitalist globalization from the 1970s and on. Now, criminalization helps displace social anxieties resulting from the structurally violent disruption of 
stability, security and social organization generated by current crisis. In her shocking expose, The New Jim Crow, legal scholar Michelle Alexander documents mass incarceration in United States as "a stunningly comprehensive and well-disguised system of racialized social control." Indeed, the racialized nature of the bogus "drug wars," of mass caging, and of the social death sentences that this hands down, is so blatant it shocks the senses. In analytical abstraction, mass incarceration takes the place of concentration camps. The system subjects a surplus and potentially rebellious population of millions to concentration, caging, and state violence. The socalled (and -declared) "war on drugs" and "war on terrorism," as well as the undeclared "war on gangs," "war on immigrants," and "war on poor youth,” must be placed in this context.

Fourth, in his brilliant yet chilling study, Cities under Siege: the New Military Urbanism, Stephen Graham shows how structures and processes of permanent militarized social control systems and warfare constitute a global project that by definition is transnational. It is important to note that every country has become enmeshed in policing the global crisis as the global economy becomes ever-more invested in warfare, social violence, and state-organized coercion and repression.

Fifth and finally, although space constraints make it impossible for me to elaborate here, militarization and organized violence become accumulation strategies independent of any political objectives, and appear as structural features of the new global capitalism. Wars, mass incarceration systems, militarizing borders, detaining immigrants, developing global surveillance systems - so forth, and so on - are immensely profitable for the global corporate economy, the transnational corporations, the transnational bankers, investors, and speculators. They have a material stake in defending and expanding a global police state. Popular forces from below must be aware of what they are up against, and of the need for fundamental change in the power and property relations of global capitalism if peace and justice are to be achieved.

\section{References}

Alexander, Michelle. 2010. The New Jim Crow: Mass Incarceration in the Age of Color Blindness. New York: New Press.

Graham, Stephen. 2010. Cities Under Siege: The New Military Urbanism. London: Verso.

Hall, Stuart, Chas Critcher, Tony Jefferson, John Clarke, and Brian Roberts. 1978. Policing the

Crisis: Mugging, the State, and Law and Order. New York: Holmes and Meier Publishers.

Robinson, William I. Forthcoming 2014. Global Capitalism, Global Crisis. In press. 